\title{
Clonal Mast Cell Proliferation in Pruriginous Skin in Hypereosinophilic Syndrome
}

\author{
$\begin{array}{llll}\text { M. Wiednig } & \text { C. Beham-Schmid } & \text { B. Kranzelbinder } & \text { a. Aberer } \\ & \text { a }\end{array}$ \\ Departments of a Dermatology and ${ }^{b}$ Pathology, Medical University of Graz, Graz, Austria
}

\section{Key Words}

Hypereosinophilic syndrome - Mastocytosis . c-KIT mutation · Tryptase $\cdot$ Mast cell activation syndrome

\footnotetext{
Abstract

Background: Hypereosinophilic syndrome (HES) is defined as a high eosinophilic granulocyte count in peripheral blood and other tissues. It can be associated with clonal and non-clonal haematological neoplastic diseases. Methods: Here we present a patient with a 27-year history of pruritus, urticarial lesions, recurrent diarrhoea, depression and a monoclonal gammopathy in the setting of HES. Results: The patient presented with erythemas, disseminated plaques, papules and scaling. Eosinophils continuously increased from $14 \%$ in 2002 to $65 \%$ in 2011. Tryptase levels were $>20 \mu \mathrm{g} / \mathrm{l}$. Skin biopsies were unspecific. In the bone marrow biopsy $30 \%$ of eosinophilic differentiated precursors and $10 \%$ plasma cells were noticed. Skin and bone marrow initially not indicative for mast cell proliferation were investigated for clonal mast cell proliferation. By immunostaining, single tryptase-, CD117c- and CD25-positive mast cells were detected not only in bone marrow, but also in the skin. Molecular investigations revealed a D816V exon 17 mutation of the c-KIT gene in bone marrow and skin biopsies. Conclusion: In this patient HES was associated with high tryptase levels with 2 underlying clonal cell populations - IgGK-
}

positive plasma cells and single clonal mast cells with a high percentage of eosinophils in the bone marrow with symptoms of a clonal mast cell activation syndrome. Because of 3 minor criteria the patient finally fulfilled the criteria for systemic mastocytosis (according to the WHO). Patients with high tryptase levels and symptoms of mast cell activation syndrome should be investigated for clonal mast cell disease even in the absence of increased mast cells in the skin and bone marrow.

(c) 2013 S. Karger AG, Basel

\section{Introduction}

The hypereosinophilic syndrome (HES) is defined as a high eosinophilic granulocyte count in peripheral blood $\left(>1.5 \times 10^{9} / 1\right)$ for longer than 6 months, and infiltration of eosinophils within bone marrow, various tissues or organs, followed by damage or dysfunction of the affected organs [1]. Intolerable pruritus is the cardinal symptom of HES. Cutaneous symptoms include angio-oedema, unusual urticarial and eczematous lesions, and therapy-resistant pruriginous papules and nodules [2]. In a patient with persistent hypereosinophilia the clinician should first rule out further underlying diseases such as parasitic infection, allergic diseases, adverse drug reactions, and other common eosinophil-associated syndromes (vascu- litis, eosinophilic gastro-enteritis, eosinophilic pneumonia) [3].

A distinction is made between 3 types of HES, each accompanied by characteristic laboratory findings. The myeloproliferative type of HES is associated with other myeloproliferative diseases, occurs primarily in men, and is marked by elevated serum levels of vitamin $\mathrm{B}_{12}$ and tryptase. Accompanying clinical conditions include mucosal ulcers, splenomegaly, endomyocardial fibrosis, and other organ-based fibrotic complications. The condition may progress to acute eosinophilic leukaemia or a blast crisis $[3,4]$. The majority of patients with myeloproliferative HES have a cryptic interstitial deletion on chromosome $4 \mathrm{q} 12$, which results in the expression of a FIP1LIPDGFRA fusion protein and autonomous tyrosine kinase activity. Although myeloproliferative HES involves a stem cell mutation, clonal eosinophil expansion dominates over other bone marrow lineages [3]. The lymphocytic type of HES is characterized by increased levels of interleukin- 5 and dysregulated $\mathrm{T}$ cells which cause a polyclonal eosinophil expansion. T-cell clones might be prone to malignant transformation. Patients with lymphocytic HES mainly have cutaneous manifestations, increased serum IgE levels, and hypergammaglobulinaemia. In the idiopathic type of HES no underlying cause can be identified [5].

The HES working group further defined myeloproliferative features but un-

\section{KARGER}

(C) 2013 S. Karger AG, Base

1018-8665/13/2271-0067\$38.00/0
Elisabeth Aberer, MD

Department of Dermatology, Medical University of Graz Auenbrugger Platz 8

AT-8036 Graz (Austria)

E-Mail elisabeth.aberer@medunigraz.at 
Table 1. Haematological data over time

\begin{tabular}{|c|c|c|c|c|}
\hline & 2002 & 2008 & 2010 & 2011 \\
\hline Eos. in blood, $\times 10^{9} / 1$ & $1.0(14 \%)$ & $1.4(24 \%)$ & $4.7(41 \%)$ & $11.4(65 \%)$ \\
\hline Eos. in BM, \% & & & 20 & 30 \\
\hline Genetic markers in blood & & & PDGF-AB: - & PDGF-AB: - \\
\hline Genetic markers in BM & & & TK gene FGFR1: - & $\mathrm{c}-\mathrm{KIT}+$ \\
\hline Aberrant cell clones in BM & & & & $\mathrm{CD} 25+, \mathrm{CD} 117 \mathrm{c}+\mathrm{MC}$ \\
\hline Skin biopsies & & & & $\mathrm{c}-\mathrm{KIT}+, \mathrm{CD} 25+, \mathrm{CD} 117 \mathrm{c}+\mathrm{MC}$ \\
\hline Tryptase $(<11.4 \mu \mathrm{g} / \mathrm{l}), \mu \mathrm{g} / \mathrm{l}$ & & 24.3 & 28.1 & 28.1 and 30.0 \\
\hline Vitamin $\mathrm{B}_{12}$ levels & & & & normal \\
\hline Total IgE & & normal & & normal \\
\hline ECP $(0-24.0 \mu \mathrm{g} / \mathrm{l}), \mu \mathrm{g} / \mathrm{l}$ & & & 77.6 & \\
\hline Plasma cells in BM, $\%$ & & 10 & 10 & $>10$ \\
\hline
\end{tabular}

Eos. = Eosinophils; PDGF = platelet-derived growth factor; TK gene = tyrosine kinase gene; ECP = eosinophilic cationic protein; $\mathrm{MC}=$ mast cells; $\mathrm{BM}=$ bone marrow.
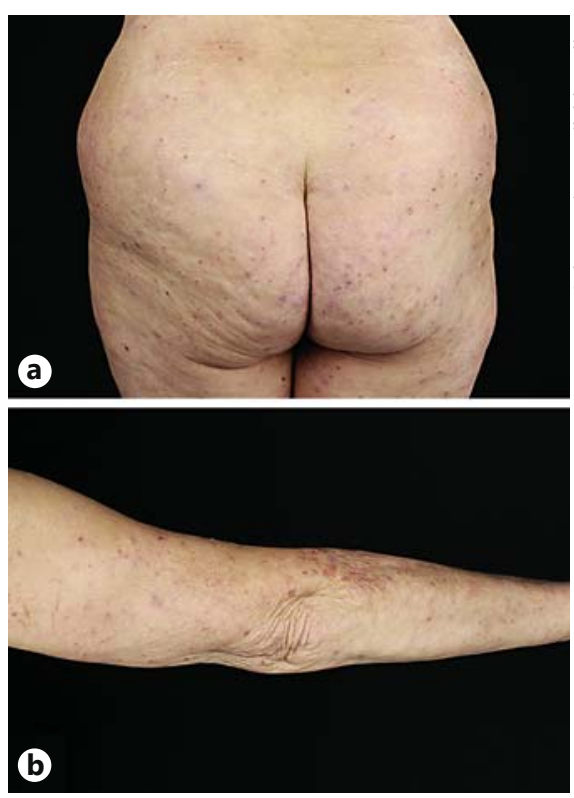

Fig. 1. a Disseminated excoriated papules on the buttocks. b Papules and plaques on the right arm.

proven clonality in HES, as well as the systemic mastocytosis (SM) type accompanied by eosinophilia $[6,7]$. Seventy to $93 \%$ of patients with SM have the D816V KIT mutation in their bone marrow cells. Mast cell invasion is seen in all tissues, also in the skin, and mediator release may cause various symptoms. One of the principal media- tors is tryptase. Persistently high serum levels $>20 \mu \mathrm{g} / \mathrm{ml}$ constitute a minor criterion for SM.

HES of long duration with recurrent skin lesions is a challenge in terms of therapy because no effective treatment is available to date. Systemic corticosteroids are effective, but eosinophilia recurs when the treatment is discontinued [8]. We report on a patient with HES, with an undetected neoplastic mast cell population in skin and bone marrow, causing local and systemic symptoms of mast cell activation.

\section{Case Report}

A 73-year-old woman with pruritus since 1975 underwent investigation at our department because of recurrent wheals and generalized papules in 2002. Her history was unremarkable except for hepatitis A and B infection in the past. Hashimoto's thyroiditis was treated with levothyroxine. The patient also suffered from recurrent diarrhoea and depression, which was suspected to be caused by intolerable and persistent pruritus treated with ketotifen. Depression had been treated with lithium. Skin lesions were located on the arms and the upper trunk and the buttocks (fig. 1a, b). The patient had erythema, urticaria, scaly lesions, and disseminated plaques with tiny papules. As she presented with white dermographism, the primary diagnosis was atopic dermatitis.
Blood count revealed eosinophilia $\left(14 \%\right.$, abs. $1.0 \times 10^{9} /$, normal range $<5 \%$; abs. $-0.7 \times 10^{9} / 1$; table 1 ) in 2002 . Total $\operatorname{IgE}$ and thyroid parameters were normal. Tryptase was not investigated at this time. Serum electrophoresis revealed IgGk gammopathy. X-rays of the chest, the paranasal sinuses, the spine and the jaw, ultrasound investigation of the abdomen, and the ENT examination were normal.

Histological investigation of 3 skin biopsies yielded similar findings: epidermal hyperplasia and hyperkeratosis with no relevant inflammation, indicating lichen simplex. A few necrotic keratinocytes were found in 1 skin specimen, accompanied by homogenous material in the papillary dermis, resembling amyloid. However, cutaneous amyloidosis was not proven in further biopsies.

The patient was treated with topical steroids (mometasone furoate, methylprednisolone aceponate) and antihistamines (hydroxyzine and ketotifen), but without significant improvement. UVB 311-nm phototherapy was started in 2003 and partial remission was achieved. The patient's pruritus and flares of skin lesions worsened and she developed pruriginous skin lesions. In 2008 eosinophils increased to $24 \%$ (abs. $\left.1.4 \times 10^{9} / 1\right)$. IgGk gammopathy was still present. As monoclonal haematological disease was suspected, a bone marrow specimen was taken. No pathologies were found. Investigation for the expression of PDGFRA fusion transcripts in blood was negative. 

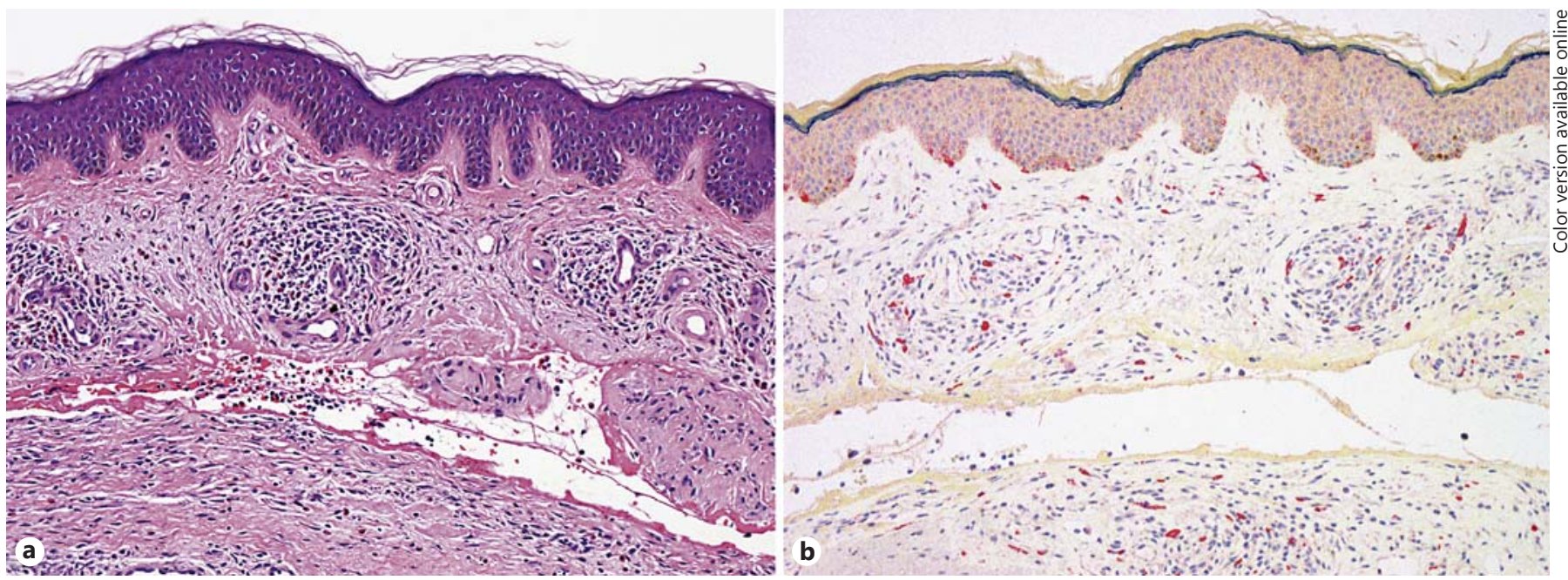

Fig. 2. a Perivascular and interstitial infiltration with lymphocytes and eosinophils in the upper dermis. HE. $\times 100$.

b Diffusely dispersed mast cells in the upper dermis. CD117c. $\times 100$.

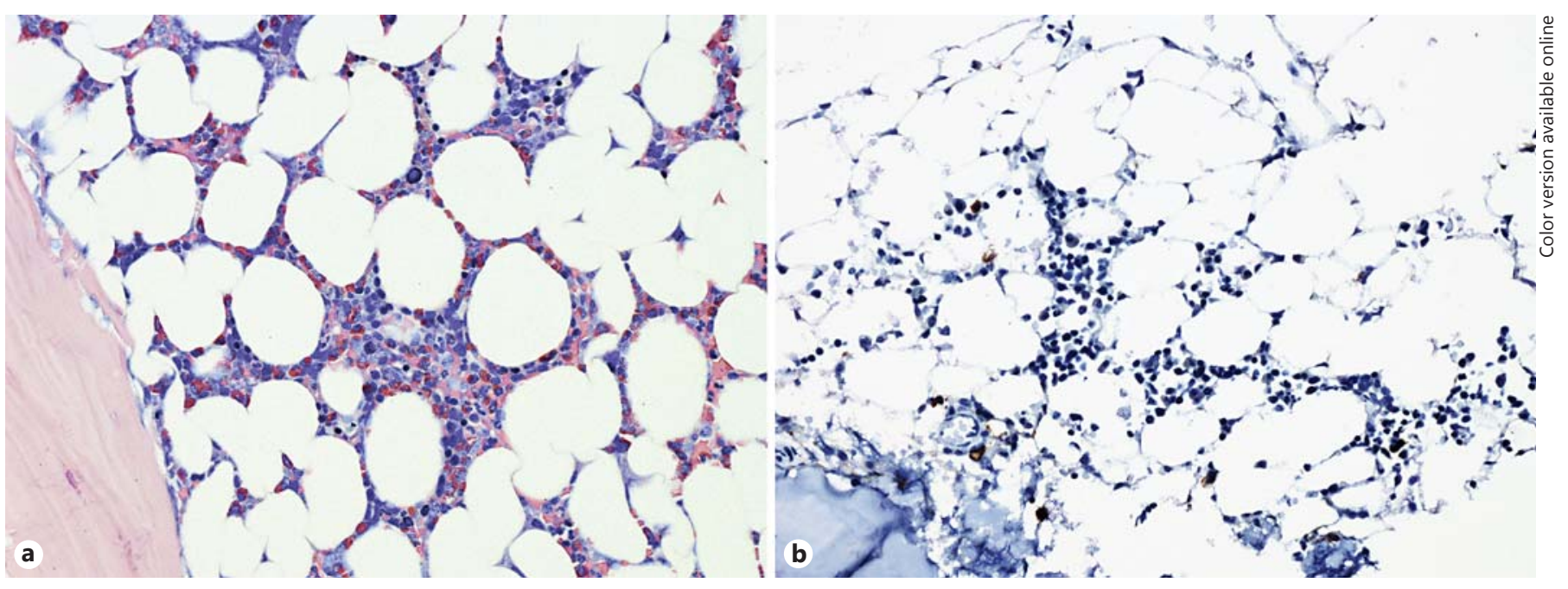

Fig. 3. a Bone marrow with increase in eosinophils and mast cells. Giemsa. $\times 400$. b Only single mast cells in bone marrow. CD117c. $\times 250$.

A further skin specimen taken in 2008 was the first to reveal perivascular and diffuse spread of eosinophils (fig. 2a). Tryptase levels at this time were $24.3 \mu \mathrm{g} / \mathrm{l}$ (normal range $<11.4$ ). The hypereosinophilic syndrome was confirmed, and treatment with systemic steroids (prednisolone 100 mg p.d.) was started. This was followed by remission of skin lesions, pruritus, and reduction of eosinophils to $6 \%\left(0.7 \times 10^{9} / 1\right)$. Therapy with 311-nm UVB was restarted and administered in conjunction with an- tihistamines. After the steroid dose had been tapered to below $12.5 \mathrm{mg}$ and was withdrawn within 2 weeks, the eosinophil count increased to $41 \%\left(4.7 \times 10^{9} / 1\right)$. Pruritus worsened and the patient's depression progressed. The bone marrow biopsy revealed $10 \%$ plasma cells with a predominance of IgGk-positive cells, but no signs of plasma cell myeloma. Treatment with methotrexate improved the patient's pruritus, but a flare occurred again after 7 months; methotrexate was discontinued. A further bone marrow biopsy performed in 2010 revealed $20 \%$ eosinophilic differentiated precursors (fig. 3a). PDGF-AB mutation and FGFR translocation were investigated in blood and found to be negative.

Another bone marrow biopsy taken in 2011 showed 30\% eosinophilic differentiated precursors and increased $\kappa$-positive cell counts. Based on the elevated tryptase level of $28.0 \mu \mathrm{g} / \mathrm{l}$, intolerable pruritus, depression, and osteoporosis (which had been diagnosed in the meantime), we sus-
Clonal Skin Mast Cells in Hypereosinophilic Syndrome
Dermatology 2013;227:67-71 DOI: $10.1159 / 000351807$ 
Table 2. Clinical symptoms in systemic mastocytosis, mast cell activation syndrome (MCAS) and symptoms of the patient

\begin{tabular}{llll}
\hline Symptoms & $\begin{array}{l}\text { Masto- } \\
\text { cytosis }\end{array}$ & $\begin{array}{l}\text { MCAS } \\
{[11]}\end{array}$ & $\begin{array}{l}\text { Pa- } \\
\text { tient }\end{array}$ \\
\hline Skin & & & \\
Flush & $\mathrm{x}$ & $\mathrm{x}$ & \\
Urticaria & $\mathrm{x}$ & $\mathrm{x}$ & $\mathrm{x}$ \\
Pruritus & $\mathrm{x}$ & $\mathrm{x}$ & $\mathrm{x}$ \\
Angio-oedema & $\mathrm{x}$ & $\mathrm{x}$ & \\
\hline Gastrointestinal tract & & & \\
Nausea & $\mathrm{x}$ & & $\mathrm{x}$ \\
Diarrhoea & $\mathrm{x}$ & $\mathrm{x}$ & $\mathrm{x}$ \\
Splenomegaly & $\mathrm{x}$ & & $\mathrm{x}$ \\
\hline Respiratory symptoms & & \\
Nasal congestion & & $\mathrm{x}$ & \\
Wheezing & $\mathrm{x}$ & $\mathrm{x}$ & \\
Nasal pruritus & & $\mathrm{x}$ & \\
Laryngeal oedema & $\mathrm{x}$ & \\
\hline Neurological symptoms & & \\
Depression & $\mathrm{x}$ & & $\mathrm{x}$ \\
Headache & $\mathrm{x}$ & $\mathrm{x}$ & \\
Vertigo & $\mathrm{x}$ & & $\mathrm{x}$ \\
Fatigue & $\mathrm{x}$ & & $\mathrm{x}$ \\
Syncope & $\mathrm{x}$ & & \\
\hline Bones & & & \\
Osteoporosis & $\mathrm{x}$ & & $\mathrm{x}$ \\
Bone pain & $\mathrm{x}$ & & $\mathrm{x}$ \\
\hline Other & & & \\
Hypotension & $\mathrm{x}$ & $\mathrm{x}$ & \\
Tachycardia & $\mathrm{x}$ & & \\
Anaphylaxis & $\mathrm{x}$ & & \\
\hline & & & \\
\hline
\end{tabular}

pected a mast cell activation syndrome. Bone marrow was stained with mast cell markers and revealed single tryptase-, CD117c- and CD25-positive mast cells (fig. 3b). Molecular investigation of bone marrow revealed a D816V exon 17 mutation of the c-KIT gene, but a negative FIP1L1-PDGFR mutation. Skin biopsies were taken again, and diffusely dispersed CD117c- and CD25-positive mast cells were found (fig. 2b). The c-KIT mutation was also proven in these biopsies.

Thus, the final diagnosis was clonal SM with associated clonal haematological nonmast cell lineage disease clinically presenting as a hypereosinophilic syndrome with $\kappa$-type monoclonal gammopathy and severe mast cell activation syndrome. Despite
Table 3. Diagnostic criteria and causes of mast cell activation syndrome (adapted from Brockow [9])

\section{Diagnostic criteria}

- Typical clinical symptoms (table 2)

- Elevation of serum tryptase level over $20 \%$ of the normal range plus $2 \mathrm{ng} / \mathrm{ml}$ during or within $4 \mathrm{~h}$ after a symptomatic episode

- Efficacy of antihistamines or other medication against mast cell activation (e.g. chromoglycinic acid)

\section{Causes}

Primary

- Mastocytosis

- Monoclonal mast cell activation syndrome

Secondary

- Allergic diseases

- Mast cell activation in chronic inflammatory, auto-immunological or neoplastic diseases and other hypersensitivity syndromes (drugs, bacteria)

- Physical urticaria

Idiopathic

- Idiopathic urticaria/angio-oedema

- Idiopathic anaphylaxis

- Other

a negative FIP1L1-PDGFRA mutation, treatment with the tyrosine kinase inhibitor imatinib mesylate $\left(\right.$ Glivec $^{\circledR} 100 \mathrm{mg} /$ day) was started. The treatment improved pruritus, but had to be discontinued after 6 months because of recurrent skin lesions and worsening of depression. Hydroxycarbamide (Litalir ${ }^{\circledR}$ ) was not tolerated, so the patient was again given systemic steroids (prednisolone $0.5 \mathrm{mg} / \mathrm{kg} /$ day) and 4 -fold doses of antihistamines. In spite of that after tapering of prednisolone below $12.5 \mathrm{mg}$, new skin lesions developed. Dasatinib monohydrate (Sprycel ${ }^{\circledR} 100 \mathrm{mg} /$ day) was then initiated by the haematologists. After 3 months, marked improvement was noted and eosinophils decreased to $24 \%\left(1.4 \times 10^{9} / 1\right)$.

\section{Discussion}

We report on a patient with chronic pruritus for 25 years, who developed progressive unspecific skin lesions, erythema, wheals and papules with the histological pattern of lichen simplex chronicus. Pruritus and skin lesions worsened in the years that followed. Notable features were increasing eosinophils in blood and elevated tryptase levels, which raised the suspicion of underlying systemic mastocytosis. As these cells were not increased in number, they were therefore not identified before in skin or bone marrow, but after a special search, CD25 positivity and a c-KIT mutation were demonstrated in the skin and bone marrow. Clinical symptoms were typical of the 'mast cell activation syndrome' which is marked by pruritus, depression, and diarrhoea, increase in tryptase, and response to antihistamines $[9,10]$. The patient had the typical symptoms but no complete response to antihistamines (table 2). From the clinical manifestations of mastocytosis, flushing, abdominal pain, diarrhoea, hives, cognitive dysfunction, osteoporosis, our patient had the latter 4 symptoms (table 2).

Two well-described acquired molecular defects have been reported to result in mast cell proliferation: a point mutation of the c-KIT gene and a rearrangement of the FIP1L-1-PDGFRA fusion transcript, associated with eosinophilic leukaemia and increased mast cell counts [11].

Our patient had a c-KIT mutation and a clonal CD25-positive mast cell population in the skin and bone marrow but no typical skin lesions clinically and histologically which occur in mastocytosis. The most common of these are the maculopapular variant of urticaria pigmentosa, plaque and nodular forms, diffuse cutaneous mastocytosis, and telangiectasia macularis eruptiva perstans [11]. For the diagnosis of systemic mastocytosis according to the WHO [12] the patient had 3 minor criteria - a c-KIT mutation, CD25-positive mast cells in bone marrow or other tissues and tryptase levels $>20 \mathrm{ng} / \mathrm{ml}$; she further had a monoclonal IgGk gammopathy, thus 2 clonal cell populations. So even in the absence of typical clinical lesions the patient expressed a primary clonal mast cell activation syndrome (table 3 ).

Systemic mastocytosis is a challenge in terms of treatment. As in our patient, corticosteroids have a transient effect. Therapy with 311-nm UVB stabilized the disease for a short while - an effect also observed recently in connection with mastocytosis [12]. Although the PDGFRA fusion protein was negative in our patient, treatment with the tyrosine kinase inhibitor imatinib mesylate was started, but had to be stopped after 6 months because it was ineffective. The response rate for imatinib in SM with 
eosinophilia was reported to be $<20 \%$ in a recent study [13]. Like dasatinib, this drug is more effective in other c-KIT mutations. In our patient improvement of skin lesions was noted. Other treatment protocols suggest that hydroxyurea, interferon- $\alpha$, 2-chlorodeoxyadenosine, hydroxycarbamide and cladribine are effective to a varying extent [13-15].
This case report underlines the fact that tryptase levels are an important diagnostic criterion that should be investigated in patients with chronic pruritus, HES or in patients with other haematological abnormalities accompanied by signs of mast cell activation such as pruritus, depression, osteoporosis, and various types of skin lesions. When basal tryptase levels are persis- tently higher than $20 \mu \mathrm{g} / \mathrm{l}$, the investigation should include skin and bone marrow staining for aberrant mast cell markers such as CD2 and CD25. Investigation of the c-KIT gene should follow when the latter findings are pathological.

\section{References}

1 Chusid MJ, Dale DC, West BC, Wolff SM: The hypereosinophilic syndrome: analysis of fourteen cases with review of the literature. Medicine 1975;54:1-27.

-2 Plötz SG, Hüttig B, Aigner B, Merkel C, Brockow K, Akdis C, Darsow U, Ring J: Clinical overview of cutaneous features in hypereosinophilic syndrome. Curr Allergy Asthma Rep 2012;12:85-98.

-3 Roufosse F, Weller PF: Practical approach to the patient with hypereosinophilia. J Allergy Clin Immunol 2010;126:39-44.

-4 Bain BJ, Fletcher SH: Chronic eosinophilic leukemias and the myeloproliferative variant of the hypereosinophilic syndrome. Immunol Allergy Clin North Am 2007;27:377-388.

5 Mossig F, Richardt G, Merten C, Gross WL: Hypereosinophilic syndrome. Internist 2013; 54:426-433.
6 Klion AD, Bochner BS, Gleich GJ, Nutman TB, Rothenberg ME, Simon HU, Wechsler ME, Weller PF, the Hypereosinophilic Syndromes Working Group: Approaches to the treatment of hypereosinophilic syndromes: a workshop summary report. J Allergy Clin Immunol 2006;117:1292-1302.

7 Simon HU, Rothenberg ME, Bochner BS, Weller PF, Wardlaw AJ, Wechsler ME, Rosenwasser LJ, Roufosse F, Gleich GJ, Klion AD: Refining the definition of hypereosinophilic syndrome. J Allergy Clin Immunol 2010;126:45-49.

8 Helbig G, Kyrcz-Krzemien S: Diagnostic and therapeutic management in patients with hypereosinophilic syndromes. Pol Arch Med Wewn 2011;121:44-52.

-9 Brockow K: Mastzellaktivierungssyndrome. Hautarzt 2013;64:102-106.

10 Akin C, Valent P, Metcalfe DD: Mast cell activation syndrome: proposed diagnostic criteria. J Allergy Clin Immunol 2010;126:1099_ 1104.

-11 Amon U, Hartmann K, Horny HP, Nowak A: Mastocytosis - an update. J Dtsch Dermatol Ges 2010;8:695-711.
12 Brazzelli V, Grasso V, Manna G, Barbaccia V, Merante S, Boveri E, Borroni G: Indolent systemic mastocytosis treated with narrowband UVB phototherapy: study of five cases. J Eur Acad Dermatol Venereol 2012;26:465-469.

13 Valent P, Akin C, Sperr WR, Escribano L, Arock M, Horny HP, Bennett JM, Metcalfe $\mathrm{DD}$ : Aggressive systemic mastocytosis and related mast cell disorders: current treatment options and proposed response criteria. Leuk Res 2003;27:635-641.

14 Lim KH, Pardanani A, Butterfield JH, Li CY, Tefferi A: Cytoreductive therapy in 108 adults with systemic mastocytosis: outcome analysis and response prediction during treatment with interferon-alpha, hydroxyurea, imatinib mesylate or 2-chlorodeoxyadenosine. Am J Hematol 2009;84:790-794.

15 Hellmann A: Myeloproliferative syndromes: diagnosis and therapeutic options. Pol Arch Med Wewn 2008;118:756-760. 